\title{
Ethanol/Chloroform Precipitation-based PCR Amplifiable Method for DNA Extraction from the Human Skeletal Remains Recovered from Gandhara Grave Sites in Pakistan
}

\section{Basit $A^{*}$ and Hilal $M$}

Taxila Institute of Asian Civilizations, Quaid-i-Azam University, Islamabad, Pakistan

\begin{abstract}
The study of DNA extraction from bones is an important part of archaeogenetics. This study has provided a new investigating power to view and understand the human past. Gandhara Graves are widespread throughout the Gandhara region, from Bajaur to the Indus in Pakistan. The graves are not only widespread throughout Gandhara but other regions (the areas east-of the Indus River) as well. Dani has divided Gandhara Graves into three distinct groups belong to three distinct periods. In the present article, the systematic research has been undertaking by the researchers to isolate DNA from the fragments of human skeletal remains recovered from Gandhara graves. Although in this regards the researchers have mentioned novel methods that could be used for DNA extraction but the only method applied is ethanol/chloroform precipitation-based PCR amplifiable method for DNA Extraction from the human skeletal remains recovered from Gandhara grave sites.
\end{abstract}

Keywords: DNA extraction; Archaeology; Paleopathology; Genetic disorder; Chloroform

\section{Introduction}

In archaeological investigation DNA analysis has proven to be a valuable resource in tracing pre-historic population movement. This DNA technique has long been applied by archaeologists anthropologist and scientist to the recognition of biological components of human remains. It has been used to show the material cultural significance excavated from the archaeological sites.

Gandhara Grave Culture emerged c. 1600 BC, and flourished c. 1500 BC to 500 BC. Gandhara Graves are widespread throughout the Gandhara region, from Bajaur to the Indus in Pakistan. Dani (1968: 108) has divided Gandhara Graves into three distinct groups belong to three distinct periods. According to Dani, Period I Represented by the complete burial: bronze hairpins, two varieties and distinctive pottery types carinated, narrow-waisted, tall drinking vases and offering stands with straight-sided bowls. Period II Represented by the complete burial plus cremation and urn burials. Bronze, silver, and gold are found. Two more varieties of bronze hairpins are known. Pottery forms show remarkable evolution. The most important forms are the urns of different sizes, cooking vessels on stands, and narrow-necked, bottle-shaped vases. Period III Represented by the complete burial, cremation and urn burials, plus fractional burials after exposure. The important new finds are iron tools and weapons. Among other discoveries, beads of precious stones and terracotta figurines are important innovations [1]

The present research is about the DNA extraction from ancient human skeletal remains recovered from Gandhara Grave sites. The human skeletal remains in the form of human skeletal fragments were recovered from two Gandharan Grave sites 'Juga Khat' and 'Warokay Gujjar Banr', Tehsil Kabal, District Swat, Pakistan. These skeletal remains were provided and recovered by the Taxila Institute of Asian Civilizations, Quaid-i-Azam University, Islamabad, Pakistan and the license for the archaeological survey was provided by the Directorate of Archaeology and Museums, KPK, Pakistan. These two sites have been destroyed by the local people due to agricultural activities [2-5].

\section{DNA Extraction Methods and its Approaches in Archaeology}

The analysis and recovery of DNA from ancient graves have enormous potential to shed light on a number of fields including anthropology, archaeology, paleoodontology etc. One area in particular in which the human DNA has lagged is the comparison and optimization of DNA extraction methods. Actually, the field of archaeology has three prefered extraction novel methods exist for human DNA extraction. These comprehensive methods have been conducting using human and faunal bones are comprises on Silica EDTA and Phosphate. In this process, the first group of hydroxyapatite focuses on the binding capacity of DNA. It used to disclassified the material into a different number by incubation in an EDTA buffer. Meanwhile, help to extracted DNA from that buffer. Second most important DNA extraction group concentrate on purifying DNA through incubation with chaotropic salt often known as guanidium thiocyanate. Hense other substances become washed away through this salt but it binds nucleic acid to silica. The third group of DNA extraction method is based on hydroxyapatite chromatography in which DNA is eluted in the bone matrix by using phosphate buffer [2]. In fact, these DNA methods not only used to recover DNA molecules efficiently but also inhabit subsequent enzymatic reaction preserved in the sample [6-8].

The chemistry of DNA is able to exploit its unique linear complementary standard that is based on two standard approaches PCR analysis and hybridization. In PCR system enzyme are most notably used to amplify (increase the number of) a template DNA sequences by replication. This process is defined by choice of primers which are oligonucleotides of about 20 bases in length that's why required 30-40

*Corresponding author: Basit A, PhD Scholar, Taxila Institute of Asian Civilizations Quaid-i-Azam University, Islamabad, Pakistan, Tel: 009251 9064127; E-mail: processual.archaeology@gmail.com

Received March 24, 2018; Accepted March 27, 2018; Published April 06, 2018

Citation: Basit A, Hilal M (2018) Ethanol/Chloroform Precipitation-based PCR Amplifiable Method for DNA Extraction from the Human Skeletal Remains Recovered from Gandhara Grave Sites in Pakistan. Human Genet Embryol 8: 146. doi:10.4172/2161-0436.1000146

Copyright: ( 2018 Basit A, et al. This is an open-access article distributed unde the terms of the Creative Commons Attribution License, which permits unrestricted use, distribution, and reproduction in any medium, provided the original author and source are credited. 
Citation: Basit A, Hilal M (2018) Ethanol/Chloroform Precipitation-based PCR Amplifiable Method for DNA Extraction from the Human Skeletal Remains Recovered from Gandhara Grave Sites in Pakistan. Human Genet Embryol 8: 146. doi:10.4172/2161-0436.1000146

Page 2 of 2

repeats in an amplification complementary to the beginning until the end of the template sequences to achieve its desired goals [9-11].

Apart from that in hybridization the affinity between DNA probes are sensitively estimated in a manner analogous to immunochemical reaction through its compositional structure and test. In this method, if probes are sufficiently homologous than bind to a complementary DNA [3].

\section{Ethanol/Chloroform Precipitation-based PCR Amplifi- able Method for DNA Extraction from the Human Skel- etal Remains Recovered from Gandhara Grave Sites}

The experiment has been performed in the Department of Medical Genetics, Quaid-i-Azam University, Islamabad, Pakistan. The researchers have followed the method [4] for DNA Extraction from the Human Skeletal Remains Recovered from Gandhara Grave Sites. The method used for the DNA extraction from the skeletal remains is ethanol/chloroform precipitation-based method for DNA [4] for the extraction of DNA from ten 500-1200 years old human bones from four different Hungarian burial sites. They succesfully extracted DNA and amplifialated it in PCR [12-15].

\section{Materials and Methods}

Small fragments were separated from the skeletal remains. In order to prevent contamination, all stages were carried out under sterile conditions, using latex gloves and mouth masks.

\section{DNA extraction}

Surface material was removed from the samples of skeletal remains. The samples were washed with ethyl alcohol and distilled water. The surface of samples was removed and only the inner part of the sample was ground into a sterile agate mortar and converted into powder form.

Powdered sample was suspended in $1.6 \mathrm{ml}$ extraction buffer $(0.1 \mathrm{M}$ EDTA, $0.5 \% \mathrm{~N}$-lauryl sarcosine-Na salt, $100 \mathrm{mg} / \mathrm{ml}$ proteinase $\mathrm{K}$ ), vortexed and incubated overnight at $37^{\circ} \mathrm{C}$ with continuous vertical rotation. After phase separation by centrifugation at room temperature 12000 r.p.m for 10 min, the $250 \mu \mathrm{l}$ supernatant was transferred to a $1.5 \mathrm{ml}$ Eppendorf tube and $3.5 \mu \mathrm{l} 1 \mu \mathrm{g} / \mu \mathrm{l}$ Dextran Blue, $250 \mu \mathrm{l} 4 \mathrm{M} \mathrm{NH} 4$-acetate and $500 \mu \mathrm{l} 96 \% \mathrm{EtOH}$ were added and mixed by vortexing. PCR is inhibited in a dose-dependent manner at concentrations of Dextran Blue only $>125 \mu \mathrm{g} / \mathrm{ml}$. The DNA was precipitated at $70^{\circ} \mathrm{C}$ for $7 \mathrm{~min}$ and centrifuged at 14000 r.p.m at $4^{\circ} \mathrm{C}$ for 15 min. The pellet was redesolved in $20-30 \mu \mathrm{l}$ deionised, distilled water. The remaining extract was stored at $20^{\circ} \mathrm{C}$.

\section{Amplification}

A typical amplification reaction contained 2-7 $\mu$ l of bone extract, $1 \mathrm{U}$ Taq DNA polymerase, $160 \mu \mathrm{g} / \mathrm{ml} \mathrm{BSA}, 200 \mu \mathrm{M}$ each of dNTP, 20 pmol each of mtDNA-specific primers, 1x PCR Buffer in $25 \mu$ total volume. Denaturation was at $93^{\circ} \mathrm{C}$ for $5 \mathrm{~min}$, followed by 35 cycles of denaturation at $93^{\circ} \mathrm{C}$ for $1 \mathrm{~min}$, annealing at $58^{\circ} \mathrm{C}$ for $1 \mathrm{~min}$ and extension at $72^{\circ} \mathrm{C}$ for $1 \mathrm{~min}$. The last cycle was followed by an extra extension step at $72^{\circ} \mathrm{C}$ for $5 \mathrm{~min}$. Amplification reactions were prepared in a PCR box using dedicated pipettes that had never been in contact with amplified DNA.

In order to check the fragment size and quality of amplification onefifth of the PCR product were run on a 5\% native polyacrylamide gel.

\section{Results}

Ethanol/chloroform precipitation-based PCR amplifiable method is efficient and easy for DNA extraction from ancient bones and the method made it possible to extract DNA from the Human Skeletal Remains Recovered from Gandhara Grave Sites. However, DNA sequencing will be carried out in the future. Chemicals and equipment mentioned in the method are available in Pakistan. Therefore ancient DNA extraction is possible in Pakistan.

\section{Discussion}

In Pakistan, there is no research in the field of archaeogenetics. The present paper will contribute in initiating such type of researches in Pakistan. Ethanol/chloroform precipitation-based PCR amplifiable method is a novel method in Pakistan for the study of ancient bones. It is very simple and effective for DNA extraction from ancient bones. The method does not require any special devices. Therefore, the method can be used very easily for the study of ancient bones. DNA extraction from ancient bones is not an easy job but this method is very successful for PCR amplification.

\section{Conclusion}

The use of most advancing technique of DNA extraction enables us to know about the genetics relationship, paleopathology, sex and genetic disorder from the skeleton remains. This particular study remarkably opens the new frontier in archaeogenetics. The use of Ethanol/chloroform precipitation-based PCR amplifiable method provides great information to the archaeological science of Gandhara graves. Finally, the result suggests that Ethanol/chloroform precipitation-based PCR amplifiable method is efficient and easy for DNA extraction from the ancient bones. Moreover, the combination of its sensitivity and specificity has enabled it to become the major technique in Pakistan to understanding ancient DNA.

\section{References}

1. Gotherstorm AH (1968) Gandhara Grave Complex in West Pakistan Asian Perspectives XI.

2. Gotherstorm A, Listen K (1996) A modified DNA extraction method for bone or teeth. J Archaeol Sci 9: 53-56.

3. Hedges REM, Sykes BC (1992) Bio-molecular archaeology: past present and future. Proc Br Acad 77: 267-283.

4. Kalmár T, Bachrati CZ, Marcsik A, Raskó I (2000) A simple and efficient method for PCR amplifiable DNA extraction from ancient bones. Nucleic Acids Res 28: E67.

5. Bruce A, Alexander J (2014) Molecular biology of the cell. Garland science Inc

6. Hagelberg E, Sykes B, Hedges R (1989) Ancient bone DNA amplified. Nature 342: 485.

7. Horsburgh KA, Kaestle FA (2002) Ancient DNA in archaeological methods application and ethics. Yearbook of physical anthropology. 45: 92-130

8. Horai S, Hayasaka K, Murayama K, Wate N, Koike H, et al. (1989) DNA amplification from ancient human skeletal remains and their sequence analysis. Proc Jpn Acad Ser B 65: 229-233.

9. Hummel S, Herrmann B (1995) aDNA analysis in palaeopathology: Mini-review and prospects. Paleopathol Newsl 91: 6-9.

10. Höss M, Pääbo S (1993) DNA extraction from pleistocene bones by a silicabased purification method. Nucleic Acids Res 21: 3913-3914.

11. Mays S (1998) The Archaeology of Human Bones. London: Routledge, UK.

12. Richards MB, Sykes BC, Hedges REM (1995) Authenticating DNA extracted from ancient skeletal remains. J Archaeol Sci 22: 291-299.

13. Shinoda K, Kunisada T (1994) Analysis of ancient Japanese Society through mitochondrial DNA sequencing. Int J Osteoarchaeol 4: 291-297.

14. Stone AC, Milner GR, Pääbo S, Stoneking M (1996) Sex determination of ancient human skeletons using DNA. Am J Phys Anthropol 99: 231-238.

15. Thomas KD (1993) Molecular biology and archaeology: A prospect for interdisciplinary research. World Archaeol 25: 1-17. 